\title{
THE MEDICAL RESOURCES AND PRACTICE OF THE CRUSADER STATES IN SYRIA AND PALESTINE \\ $1096-1193$
}

by

ANN F. WOODINGS

AT THE end of the eleventh century a spate of intellectual activity in all fields, usually known as the Twelfth-Century Renaissance, began in Western Europe. Medical knowledge, consequently, made considerable advances with the rediscovery, mainly from Arabic sources, of Ancient Greek medical texts and with the translation of the works of skilled Arabic doctors who practised according to Greek principles. This information filtered into Europe from two points where Moslems and Christians met, the kingdoms of Sicily and Spain. But, during the same period, another point of contact was established.

The restlessness of growing Europe was harnessed, due to the interaction of many factors, to the notion of Holy War against Islam. In 1096, in response to a call by Pope Urban II, many people, both rich and poor, left their homes to go to Palestine to reconquer Jerusalem from the Turks. Thus, while scholars at Monte Cassino, Montpellier, Toledo and Barcelona patiently translated Galen, Hippocrates, Haly Abbas and Avicenna from the Arabic, Christians clashed with Moslems and sought immediate practical remedies for their wounds.

The purpose of this essay is to discover what benefit, if any, the Franks derived from this direct confrontation with more advanced Moslem medical science. The medical facilities available in Syria and Palestine the training and examination of doctors, the development in these spheres, the adaptations and innovations made by the Franks in their own practice to combat the conditions of warfare in the East, therefore, will be examined.

Medical knowledge had been well established in Syria and Palestine in the fifth century by Nestorian Christians who had fled in $\mathbf{4 3 1}$ from persecution in Alexandria, the great university and centre of Greek learning in the classical world. Centres for medical study, staffed by Nestorians and Jacobite clergy continued to flourish at Jerusalem, Antioch and Tripoli throughout the Latin occupation of Syria and Palestine; thus the Crusaders had an assured supply of skilled doctors. The Franks almost immediately recognized the value of these schools. In 1103, Baldwin I, gravely wounded in a fight with brigands who infested the route from Caiffa to Caesarea, had himself carried to Jerusalem where he knew the most skilful doctors were to be found.

The Latins were also fortunate in discovering many hospices already established by 1098. Fetellus and Saewulf both mention a hospital for the poor to the south of Jerusalem, which was probably that founded by Charlemagne. Fetellus also mentions 


\section{Medical Resources and Practice of the Crusader States}

a Hospital Xenodochium in Jerusalem 'where the sick are gathered from the streets and the villages and taken care of'. ${ }^{1}$ That it might be an old foundation Fetellus suggests when he says: 'Hyrcanus, the prince of the Jews, is said to have been the first to institute Xenodochia with the money he abstracted from the Sepulchre of David.'2 A hostel had been set up by the merchants of Amalfi probably before 1070 .

The Franks' ability to organize and improve upon existing facilities was soon exhibited. The doctors in the States ruled by the Crusaders became subject to regulations. Contained in the Livres des Assises de la Cour des Bourgeois (c. 1173-87) are three chapters detailing the procedure to obtain a licence to practise. 'Encement nul miege estranger, ce est qui veigne d'outremer ou de Painime, ne det meger d'orine nuluy jusques a ce que il soit esprouves par autres mieges, les meillors de la terre, en la presence dou vesque de la terre, qui se det destre fait'. ${ }^{3}$

That an Arab doctor, or one who had lived in a Moslem country, was examined in the same manner as a Frank or native of the Outremer, is a clear reflection of the confidence enjoyed by Arab medicine among the Crusaders. It is also significant, in the light of the abilities of the Jacobite priesthood, to find a Latin bishop considered a fit person to test a doctor's knowledge. The successful candidate received letters authorizing him to practise only in the town in which he resided. A doctor, practising without these letters, was beaten and thrown out of town.

The doctors also assumed a heavy responsibility in law. The wording of the law also gives us an indication of their methods of business. A doctor was judged negligent and liable to pay compensation if, three days after the master and he had agreed upon a price for curing a wounded slave, he guaranteed, after further examination, the patient's recovery and the slave died. Similarly, if the slave died as the result of the doctor, in effecting a cure, cutting the abscess across when it should have been cut lengthwise, he had to indemnify the master.

It is also very instructive to find the Assises stipulating what were considered correct remedies, not only because it tells us what the best practice of the day was, but also because it implies some common body of knowledge and agreement among practitioners. This last was likely while the great Syrian and Palestinian medical schools flourished. One passage deals with compensation for a slave who died as a result of his illness being wrongly treated.4 A doctor had to pay the master the price of the slave if he had used laxatives and 'hot' medicines to treat diarrhoea and diseases of a hot nature, 'cold' drugs to treat diseases of a cold nature, excessive doses of 'scamminee' for a quotidian fever. If he failed to file the bone fragments from a fracture of the skull complicated by cerebral lesions, or had removed too little liquid, or taken hot liquid too quickly from a dropsical stomach, he was similarly liable. In the case of a slave who recovered after wrong treatment, but was infirm or an invalid as a result, the doctor 'est tenue de prendre celui serf et de paier a son seignor tant come il li a costé'. ${ }^{5}$ If he could not find so large a sum, he had to pay a sum equal to the depreciation in the slave's value. The Assises, in using the term 'hot' and 'cold'

1 Fetellus, 'Pilgrimages', PPTS, Vol. V, p. 2.

2 Ibid., p. 39.

Recueil des Historiens des Croisades (Lois), Tome II, Ch. CCXXXVI.

op. cit.

op. cit., Ch. CCXXIX. 


\section{Ann F. Woodings}

to describe diseases and remedies, were making the Hippocratic theory of humours the basis of correct medicine.

Although a doctor could be faced with what amounted to a large fine if he erred in treating a slave, the consequences for likewise treating a free man were severe. He could be beaten and then hanged, and his fee refunded to his late patient's heirs. However, he was allowed to argue certain points in his defence. He could go free, if he could prove that, contrary to his advice, the patient had indulged in sexual or alcoholic excesses, or eaten harmful foods. This great responsibility in law may have been one factor which influenced the Greek and Syrian doctors against treating King Amalric, who was suffering with dysentery, with a purgative. ${ }^{6}$

How insecure a doctor could be is illustrated by an incident in Tyre in 1189. Conrad of Montferrat was afflicted by a complaint to which he had long been accustomed. As, on one occasion, the attack was worse than usual, he thought he had been poisoned. He therefore issued harsh edicts against physicians who made potions. Innocent men, as a result, were put to death on false suspicions. As Geoffrey de Vinsauf said, "those whose province it was to heal others, now found the practice of their art led to their own destruction.'?

Among the Arabs, who had a separate court from the Latins, more equitable methods were in force. After each visit, the doctor's injunctions were noted down and, if the patient died, these were taken to the head of the doctors. He then examined them to see if there had been any neglect or imprudence on the part of the doctor. It would be interesting to know who this man was and how he was selected. The main point is, however, that the Franks were not influenced in their practice by the observation of Arab methods.

The peripheral medical professions-oculists, scarifiers, and surgeons were included in this category-were also inspected. The Mathessep, the lieutenant of the viscount of the 'bailli' and head of the sergeants of the Cour des Bourgeois, was detailed to carry out this inspection and execute any sanitary regulations. In this way, the Latins, finding themselves well supplied with doctors in 1098, organized them in order to test their ability and guard the public against their negligence.

The disparity between Arab and Frankish medicine is clearly brought out by Usamah Ibn Munqidh, an Arab nobleman from Shaizar, who wrote his memoirs shortly before his death in $1180 . .^{8}$ Usamah also refers to incidents relating to older members of his family. The Lord of al-Munaytirah wrote to Usamah's uncle to ask for a physician to be sent to treat some of his sick people. A Christian doctor, Thabit, was sent, but returned in disgust after ten days. He explained why. Two patients were produced, one a knight with an abscess on his leg and the other an imbecile woman. Thabit put a small poultice on the knight's leg until the abscess opened and started to heal. He placed the woman on a special diet to make her humour wet, and she began to improve. This treatment was based on the Hippocratic classification of diseases into wet or dry, hot or cold. One administered a remedy of the opposite nature to the disease. At this point, a Frankish physician arrived who discredited

- William of Tyre, A History of Deeds done beyond the Seas, Bk. 20, p. 395.

${ }^{7}$ Geoffrey de Vinsauf, Itinerary...., Ch. XXVI, p. 103.

8 Usamah ibn Munqidh, An Arab-Syrian Gentleman and Warrior . ..., ed. and trans. P. K. Hitti, Columbia University Press, 1929. 


\section{Medical Resources and Practice of the Crusader States}

Thabit's knowledge. He told the knight that he would die unless his leg was cut off. The knight agreed to this and a brawny knight with a sharp axe was brought in. At the first blow the patient died. The imbecile, the Frank announced, had a devil in her head. Thus he had her hair shaved off and put back on an ordinary diet. Her imbecility became worse; whereupon the physician said the devil had penetrated through her head. He then produced a razor, made a deep cruciform incision in her skull, peeled off the skin in the middle until bone was exposed. He rubbed salt in the wound and the woman immediately died. This last remedy seems especially gruesome, but it was one described by Roger of Salerno and, therefore, recognized Frankish practice. William of Bures, Lord of Tiberias, told Usamah that he called in a priest to minister to a sick knight. The priest, on seeing the patient, asked for wax. With this he plugged the patient's nose so that he died. He explained that he had done this as the man was in such pain that death seemed preferable.

After these anecdotes, it would appear that Frankish medicine was indeed barbarous. Yet Usamah also has tales of two good cures effected by Franks. A Frankish physician in Shaizar gave an artisan an efficacious remedy for scrofula, which Usamah himself later used successfully. Bernard, the treasurer of King Fulk, was kicked by a horse. The wound became infected and opened in fourteen different places. A Frankish doctor who was called in removed all the ointments on his leg and washed it in a very strong vinegar. The cut then gradually healed. This is interesting, for alcohol is a good disinfectant and its use is suggested in Arabic works. ${ }^{10} \mathrm{Hugh}$ of Lucca, who learnt a great deal from the Arabs at the siege of Damietta in 1214, used wine in a similar way. The above instance, however, shows an even earlier example of Arabic influence on Western medicine, as Fulk died in 1143.

In the sphere of preventive medicine, similar texts were available to both sides by the end of the twelfth century. Ali Ibn-Rabban, his pupil Rhazes, and Avicenna all include large sections in their books on climate, waters and seasons in relation to health. Their strictures could have become well known by the twelfth century, for E. G. Browne has remarked 'how general was the interest taken in medical topics in the medieval Muslim World'.11

On the Franks' part, acquaintance with these medical works was of a later date. Gilbertus Anglicus, who probably studied at either Salerno or Montpellier, accompanied Hubert Walter on the Third Crusade. In his book, written much later, Gilbertus has chapters devoted to hygiene which had been taken from Rhazes, who had copied them from Paul of Aegina, whose ultimate source of knowledge was Diocles. Thus, presuming that native doctors had not instructed their Frankish lords before this date, at least by 1191 there were physicians on both sides possessing similar information. It is, therefore, interesting to compare the performance of the two armies in the prevention of disease.

At Antioch in 1098 the Anonymous of the Gesta Francorum records that 'at dawn, other Turks came out from the city and collected all the stinking corpses of the dead Turks . . . and buried them at the mosque.' ${ }^{12}$ The Christians however,

op. cit., p. 166.

10 Ibid.

11 E. G. Browne, Arabian Medicine, p. 73.

12 Gesta Francorum, p. 42. 


\section{Ann F. Woodings}

hearing that valuable objects had been buried with them, dug them up, extracted the valuables, and then threw the corpses into a pit. Although one can argue that affection or respect prompted the Turks' action, in the light of later Turkish deeds, it is likely that desire to prevent disease was also paramount. The greed of the Christians, which impelled them to dig up and expose these corpses, reflects their attitude to public health, and makes it no wonder that disease was prevalent in their camp.

The best examples of hygiene in siege warfare are to be found in accounts of the siege of Acre of August 1189 to July 1191. Much of the illness suffered by the Crusaders undoubtedly sprang from vitamin deficiency and malnutrition, which also weakened their resistance to disease. Richard I fell ill on arrival with 'leonardie' which seems to have been trench mouth, an ailment caused by the above two factors. In this case one must remember that conditions on board ship were bad with regard to water, food and sanitation, and many Crusaders, landing at Acre were, most probably, already ill. As the Crusaders besieging Acre were later themselves besieged and dependent on the Venetian and Genoese fleets for supplies, little blame can be attached to them for their poor sustenance.

On the other hand, with regard to burying the dead, they do appear negligent. Geoffrey de Vinsauf says that great numbers 'died in a short time by the stench of the dead bodies which corrupted the air and by the fatigue of constant watchings.' ${ }^{13}$ After one battle the Christians merely piled the bodies in the river. One is not told from where they drew their supply of drinking water! Saladin, after this action, moved his army. 'The Sultan ordered the baggage-train back as far as el Kharruba, fearing that the effluvia from the heaps of the dead might injure the health of his troops.' 14 The garrison of Acre, which had no choice about moving away from the stench, endeavoured to remove its cause. Every day they cleared the ditches of the bodies of horses and men with which the Franks filled them. This they did by dividing themselves into four groups; one cut up the animals' bodies, to make them easier to move; the second carried them off and threw them into the sea; the third maintained a constant fire of arrows on the Crusaders to protect these groups as they worked; while the fourth worked the mangonels for the same purpose. The Turks had, for a long time, been averse to suffering bad smells; for Fetellus says that Caesarea, before its capture by the Franks, had a number of small caves in which spices and aromatics were mingled in the fire so that the whole city was scented and bad smells killed. ${ }^{15}$

During the siege of Acre, the Crusaders suffered badly from malnutrition, the siting of their camp and their own bad management of the disposal of bodies. The Turks attempted to remedy these evils. Saladin moved his camp away from the plain, 'above the exhalations of the plain, that were already beginning to affect his health.'16 The garrison cleared the ditches. The Crusaders, if they wished to maintain a close blockade, had to stay on the plain, and suffered in consequence. 'The winter season which was attended with incessant rain and frequent changes of temperature, made the plain exceedingly unhealthy and caused heavy mortality among the Franks.'17

\footnotetext{
13 Geoffrey de Vinsauf, op. cit., Ch. XXXI, p. III.

14 Beha-ed-Din, Life ...., p. 269.

${ }^{16}$ Fetellus, 'Pilgrimage', PPTS, Vol. V, p. 49.

16 Beha ed Din, Life of Saladin, p. 236.

${ }^{17}$ Ibid.
} 


\section{Medical Resources and Practice of the Crusader States}

Beha-ed-Din's silence on the state of the Turkish army leads one to suppose that no untoward losses from disease were sustained. Although the Crusading army could not escape the evils of famine and bad siting, nevertheless, one feels that they did not do as much as they could to prevent rampant disease.

Although the Crusaders' arrangements in the field were poor and few adaptations to combat heat and disease were made, in Jerusalem itself the Crusaders had good facilities. The greatest hospital in Jerusalem was that of the Order of St. John, which had grown out of the hostel built by the merchants of Amalfi; a development clearly stimulated by the military situation in the holy land. Theoderich, who saw the hospital some time between 1171 and 1174 said: 'no one can credibly tell another how beautiful its buildings are, how abundantly it is supplied with rooms and beds and other material for the use of poor, and sick people, how rich it is in the means of refreshing the poor, and how devotedly it labours to maintain the needy, unless he has had the opportunity of seeing it with his own eyes. Indeed we passed through this palace, and were unable by any means to discover the number of sick people laying there; but we saw that the beds numbered more than one thousand.'18

John of Wurzburg was similarly impressed: 'in various rooms is collected together an enormous multitude of sick people, both men and women, who are tended and restored to health daily at a very great expense. When I was there I learned that the whole number of these sick people amounted to 2,000, of which sometimes in the course of one day and night more than fifty die and are carried out dead, while many other fresh ones keep continually arriving . . . The same house supplies as many people outside it with victuals as it does those inside. . . . ${ }^{19}$ In view of this high turnover of patients, it is no wonder that another pilgrim remarks on the Chaudemar, just outside the walls, the burying place for those who died in the hospital, given to the Knights of St. John in 1143 by William, Patriarch of Jerusalem. Marvellous as the hospital seemed to contemporaries, the description of it given to Baurath Dr. Schick, who excavated it, is more in keeping with the death-rate. 'The whole area of the place formed one building, although consisting of various parts and often divided by narrow lanes, containing some open, but small, courts for light and air. Erected by Europeans not sufficiently experienced they were not always constructed according to the rules of health, as they were obliged to keep their animals in the building itself.' 20

Concentration on the growth of the military aspects of the Order of the Knights of St. John has led to neglect of how the hospital was organized. Nevertheless its development from a place for godly care into an institution where positive nursing took place is chronicled in the Rule and Statutes. This development also shows a recognition of the problems of a state constantly at war and the growing sophistication of Frankish medical practice.

Raymond of Puy, Master of the Hospital from 1120 until 1158/60 added to the Rule of Gerard a chapter concerning the care of the sick. 'And in the Obedience in which the Master and the Chapter of the Hospital shall permit, when the sick man shall come there, let him be received thus, let him partake of the Holy Sacrament,

18 Theoderich, op. cit., p. 22.

19 John of Wurzburg, 'Pilgrimage', PPTS, p. 44.

20 Schick, The Muristan, p. 49. 


\section{Ann F. Woodings}

first having confessed his sins to the priest, and afterwards let him be carried to bed, and there as if he were a lord, each day before the brethren go to eat let him be refreshed with food charitably according to the ability of the House.'21 The idea seems to have been to care for the patient's physical and spiritual needs and let nature effect a cure. A similar philosophy appears to lie behind a Statute passed at the Chapter-General of 1176 , called the 'Privilege of the sick to have white bread'.

The statutes of Roger des Moulins (1177-87), however, promulgated at the ChapterGeneral of 1181, mark a great step forward towards giving positive medical care at the hospital, and underline past deficiencies. The second decree is perhaps the most important as it says 'that for the sick in the Hospital there should be engaged four wise doctors, who are qualified to examine urine, and to diagnose different diseases, and are able to administer appropriate medicines.' ${ }^{22}$ Their importance is shown by the fact that they were allowed to dine at the Knights' table, not that of the sergeants.

Then followed detailed decrees to provide for the comfort of the inmates: the beds were to be as long and as broad as is 'most convenient for repose'. ${ }^{23}$ and have their own coverlets and sheets. Each sick person was to have a sheepskin cloak and boots and caps of wool for going to and fro from the latrines. ${ }^{24}$ Separate cradles for babies born in the hospital were to be provided so that they would not be disturbed by their mothers' restlessness. The brethren were to guard and watch the sick poor day and night, serving them with zeal and devotion as if they were their lords. ${ }^{25}$ In every ward nine sergeants were to be kept at the service of the sick, to wash their feet gently, change their sheets, administer to the weak necessary and strengthening food, and do their duty devotedly and obey in all things for the sick.

Further decrees deal with the annual tribute which the other priories outside the Holy Land had to make to the hospital. All tribute was in kind and for the benefit of the sick. The Priors of France and St. Gilles had to send one hundred dyed sheets to replace coverlets for the sick; the Prior of Constantinople two hundred felts for a similar purpose. The Prior of Mont Pelerin (Tripoli) and Bailiff of Tabarie (Tiberias) had to send two quintals of sugar for syrups, medicines, and electuaries for the sick. Goods of a like nature were demanded from other houses. In a confirmation by Roger des Moulins of things the hospital should do, further detail is given. Three days a week the patients were to have fresh meat, either pork or mutton. For those who were unable to eat that, chicken was to be provided. The sheepskin cloaks were now to be shared one between two inmates. A brother shoemaker and three sergeants were to repair old shoes 'given for the love of God'. More charities dispensed by the hospital are also enumerated.

The concern for more positive medical care and the employment of professional doctors is a reflection of the dangerous times for the Crusader states at the end of the twelfth century. The pages of the chronicle of William, Archbishop of Tyre, at this time, show a feeling of desperation and impending doom even before the death of King Amalric in 1174. Baldwin his son, who succeeded him, was a leper and, able as he was, clearly failing in health. In 1177750 wounded from the battle of Mont

${ }^{21}$ Rule of Raymond du Puy, Ch. 16.

22 Rules, Statutes and Customs of the Hospitallers, trans., by E. J. King, Decree 2.

23 Ibid., Decree 3.

24 Ibid., Decree 4.

25 Ibid., Decree 5. 


\section{Medical Resources and Practice of the Crusader States}

Gizard were taken to the hospital. The establishment of doctors in the hospital in 1181 was a natural consequence of this train of events, and a response to conditions of perpetual warfare and illness in a climate of extremes.

One obscure Order which seems to have adapted itself to the requirements of the Crusaders is that of St. Lazarus. Rarely mentioned in books today, its origins were once a matter of hot debate. The main body of opinion appears to support the contention that the Order was established in the fourth century, with the approval of the saintly Pope Damas, to care for lepers and that its original hospital was at Caesarea from whence it spread with the foundation of other hospitals. It seems that the Order, like that of the hospital, came to unite military and medical duties as a result of the crusades. How far it developed its medical aspects during the twelfth century is uncertain but Père Toussaint de St. Luc, one of- the Order's earliest historians, asserts that the Order ran three sorts of hospice: one to take of lepers; one to lodge pilgrims and one to tend the wounded and abandoned soldiers.

The Teutonic Order, confirmed by the Pope in 1192, arose as a result of the siege of Acre. Some Crusaders from Bremen and Lübeck formed a tent out of the sails of a boat to receive the sick people of their nation. Thereafter they resolved to establish an Order for their countrymen. They took over the Hospital of St. Mary in Jerusalem and their full title became the Order of the Hospital of St. Mary of the Germans of Jerusalem.

What work the Order of the Temple did to care for the wounded is unknown, as the documents of their Order have all disappeared. One conjectures, nevertheless, that special attention was paid to restoring wounded brothers to health, since the essence of the Order was to maintain a body of fit, fighting men.

To sum up, the provision of medical facilities in Syria and Palestine in 1098 was ample, and steadily improved and increased throughout the period. Long-established centres of medical instruction continued to flourish and were staffed by teachers of high repute.

The Crusading Franks, on their arrival, disturbed nothing but built up services for themselves upon these secure foundations. They rapidly entrusted their bodily welfare to experienced native doctors whom they seemed to prefer to their own. William of Tyre was bitter about this as he blamed a Syrian doctor, Barac, for the death of King Baldwin III. 'Our Eastern princes through the influence of their women, scorn the medicines and practice of our Latin physicians and believe only in the Jews, Samaritans, Syrians and Saracens. Most recklessly they put themselves under the care of such practitioners and trust their lives to people who are ignorant of the science of medicine.' This wholesale condemnation is unjustified as Barac's ignorance can be countered by the tales of Usamah. The continued use of native doctors (when there appears to have been a choice) by the most powerful Frankish nobles in vital matters of life and death seems to indicate not only the natives' superiority but also the Frankish doctors' neglect of the opportunities in the East to increase their knowledge and so place themselves on a par with their Eastern counterparts.

The development of the medical aspects of the Military Orders, particularly that of St. John, is the best example of the Frankish knights' adaptation to conditions of 


\section{Ann F. Woodings}

war in the East. The Statutes of the Hospitallers show a distinct trend towards more professional and competent medical treatment. Saladin himself is supposed to have been impressed by the care the Order lavished on their patients. He, indeed, allowed it to evacuate patients from Jerusalem in 1187 after he had captured the city; he even permitted ten brothers to remain behind for a year to tend those too ill to move. On the other hand hygiene on campaign did not seem to improve, and only two translations of Arabic medical texts can be traced to Palestine and Syria in this period. Thus the theory of medicine in the West was not much advanced by the Crusaders' settlement in the East. Greek and Arabic knowledge continued to be channelled almost entirely into the West via Italy and Spain.

The main benefit to Western medicine of the Crusades, therefore, seems to have been the stimulus to the organization of the Hospital of St. John. Ultimately this was of immense value; for when the Knights were locked in a death struggle with the Turks in Malta in 1565 they avoided the diseases which drastically weakened their more numerous opponents. 'The reason why the defenders in their shattered garrisons did not suffer so much as the enemy can probably be traced to the Knights' principal avocation, that of Hospitallers. Simple though their surgery was, and ignorant though they were in many ways, they did at least understand the rudiments of hygiene ... . even during the siege, some attempt was made to look after the patients properly. It was no doubt for this reason that the garrisons owed their relative freedom from the diseases which decimated the enemy.' ${ }^{26}$ If Malta had fallen in 1565 the Turkish advance begun by Saladin would have been carried into the Western Mediterranean with incalculable results for Western civilization.

${ }^{26}$ E. Bradford, The Great Siege, pp. 204-5.

\section{BIBLIOGRAPHY}

AmbroIse, The Crusade of Richard Lionheart, trans. M. J. Hubert and J. L. Lamonte, New York, Columbia University Press, 1941.

Anonymous, Gesta Francorum, trans and ed. R. M. T. Hill, London, 1962.

Anonymous PILGrims, Pilgrimages, I-VIII, trans. A. Stewart, London, Palestine Pilgrims' Text Society, 1894.

BeHA-ED-DIN, Life of Saladin, P.P.T.S., Vol. XIII, London, 1897.

ERNoul, Account of Palestine, trans. C. R. Conder, P.P.T.S., London, 1888.

Frtellus, Pilgrimage, P.P.T.S., Vol. V., London, 1896.

GeofFreY DE VINSAUF, 'Itinerary of Richard I . . .', in Chronicles of the Crusades, Bohn Library, 1900.

Ibn AL-QAlanis,, The Damascus Chronicle, trans. and ed. H. A. R. Gibb, London, 1932.

Johannes Phocas [John of Wurzburg], Account . . ., trans. in Vol. V, P.P.T.S., London, 1897.

'Livre des Assises de la Cour des Bourgeois', in Recueil des Historiens des Croisades, Lois, Tome II.

Mukkadasi, Description of Syria and Palestine, trans. in P.P.T.S., London, 1894.

Richard OF DEvizes in Chronicles of the Crusades, op cit.

Rules, Statutes and Customs of the Hospitallers, trans. E. J. King, London, 1934.

THEODERICH, Pilgrimage . . . , trans. in [P.P.T.S., Vol. V, London, 1896.

Usamah IBN MuNQIDH, An Arab-Syrian Gentleman and Warrior in the Period of the Crusades: Memoirs of Usamah . . . , ed. and trans. P. K. Hitti, New York, Columbia University Press, 1929. 


\section{Medical Resources and Practice of the Crusader States}

William OF TYRE, A History of Deeds done beyond the Seas, ed. and trans. E. A. Babcock and A. C. Krey, New York, Columbia University Press, 1943, Vols. 1 and 2.

Browne, E. G., Arabian Medicine, Cambridge University Press, 1921.

Campbell, D., Arabian Medicine, 2 vols., London, 1926.

Delaville le RoulX, J., Les Hospitaliers en Terre Sainte et a Chypre, Paris, 1904.

ElGOOD, C., A Medical History of Persia, Cambridge University Press, 1951.

Helyst, P., Histoire des Ordres monastiques, Paris, 1714.

Le H. M. J.[EUNE], Histoire critique et apolegetique de l'Ordre des Chevaliers du Temple de Jerusalem.

LAGenissiere, L. C., Histoire de l'Eveche de Bethleem, Paris and Nevers, 1872.

LANE-POOLE, S., Saladin and the Fall of the Kingdom of Jerusalem, reprinted, Beirut, 1967.

Makmauly, N., and Jorns, C. N., Guide to Acre, Jerusalem, 1946.

ReY, E. G., Les Grandes Ecoles Syriennes du IV au XIII Siècles, Paris, 1898.

REY, E. G., Les Colonies Franques de Syrie auX XII et XIII Siècles, Paris, 1883.

Schick, C., 'The Muristan, or the Site of the Hospital of St. John at Jerusalem', in Palestine Exploration Fund Quarterly Statement, January 1902, pp. 42-56.

Talbot, C. H., Medicine in Medieval England, London, 1967.

Le Pere Toussaint de St. Luc, Memoires ... de l'Ordre Royal des Chevaliers Hospitaliers de Notre Dame du Mont Carmel et de St. Lazare de Jerusalem, Paris, 1665.

WiCKERSHEIMER, E., 'Organisation et legislation sanitaires au Royaume franc de Jerusalem, 1099-1291', Arch. int. Hist. Sci., 1951, 4, 1951. 